\title{
Receptors in Oral Epithelial Innate Immunity
}

\section{Whasun 0 Chung*}

Department of Oral Health Sciences, University of Washington, USA

As the first line of defense between the outside environment and the host, epithelial tissues utilize an elaborate signaling network in the presence of colonizing bacteria. A number of signal transduction pathways and Pattern Recognition Receptors (PRRs) are involved in the bacterial-host communication and the production of innate immune responses by the host. Oral epithelia, in particular, are constantly exposed to hundreds of different species of bacteria, yet maintain healthy homeostasis. Numerous studies have reported on a complex biological system in the oral epithelia and what roles different epithelial PRRs play on the induction of appropriate innate immune responses.

Members of Toll-like receptor (TLR) family, one of the well-studied receptors, are expressed on many cell types, including macrophage, monocytes, dendritic cells and epithelial cells. They are transmembrane receptors which play a significant role in recognizing the microbeassociated molecular patterns [1]. Among the 13 TLRs identified in mammals, TLRs 1-10 are expressed in humans. The role of each TLR in innate immunity against bacteria and how TLRs active inflammatory cytokines and antimicrobial peptides have been well documented [2,3]. In addition, Asp299Gly and Thr399Ile mis-sense mutations in extracellular domain of TLR4 have been associated with decreased late diabetic complication and aggressive periodontitis $[4,5]$.

Protease-Activated Receptors (PARs) are G-protein-coupled receptors (GPCR) which can be activated via proteolytic cleavage by serine proteinases [6,7]. Among various memebrs of PAR familes, PAR2 is involved in inflammatory processes in several tissues [8-10], and the mRNA expression of PAR2 is increased in chronic periodontitis patients with high prevalence to Porphyromonas gingivalis infection [11].

Nucleotide-binding Oligomerization Domain Receptors (NODs) are cytosolic pattern-recognition molecules expressed mainly in cell types which are exposed to bacterial PGN, including epithelial cells, macrophages and dendritic cells [12-14]. Multiple studies demonstrated the role NODs play in host immune responses against microbial infection, including NOD1 protein involved in host response to Helicobacter pylori in the gastric mucosa $[15,16]$, an association of mutations in NOD2 gene with susceptibility to Crohn's disease and skin rash $[17,18]$, and localization of NOD9 in the outer membrane of mitochondria leading to interferon production in response to viral infection $[19,20]$.

A newest receptor reported to play a role in epithelial innate immunity is the bitter taste receptor T2R38 [21]. It was initially identified to regulate mucosal innate immune responses in the upper airway epithelia and lungs [22]. The T2R38 receptor was also shown to respond to Pseudomonas quorum-sensing molecules by regulating mucociliary clearance and antibacterial effects [23]. In gingival epithelia, T2R38 plays a role in the regulation of IL- $1 \alpha$ and IL-8 secretion as well as in antimicrobial peptide induction [24]. A recent study also suggests that a high level of antimicrobial peptide effective against cariogenic bacteria is induced by particular SNP carriers who have demonstrated protection against caries [24].

In the oral cavity, where hundreds of microorganisms interact with host tissue, it is essential that the host produces appropriate innate immune responses for different bacteria present. As it is reasonably expected, oral epithelial cells have been shown to balance receptor expression for specific bacterial recognition and subsequent innate immune responses and cytokine production $[25,26]$. These studies reveal how appropriate host epithelial innate immune responses to different bacteria are induced by balancing multiple receptors. As various bacterial virulence factors activate different receptors of innate immunity, interaction of different receptors may be crucial in determining host defense responses.

\section{References}

1. Kaisho T, Akira S (2006) Toll-like receptor function and signaling. J Allergy Clin Immunol 117: 979-987.

2. Medzhitov R, Janeway C Jr (2000) The Toll receptor family and microbial recognition. Trends Microbiol 8: 452-456.

3. Schiller M, Metze D, Luger TA, Grabbe S, Gunzer M (2006) Immune response modifiers-mode of action. Exp Dermatol 15: 331-341.

4. Rudofsky G Jr, Reismann P, Witte S, Humpert PM, Isermann B, et al. (2004) Asp299Gly and Thr399lle genotypes of the TLR4 gene are associated with a reduced prevalence of diabetic neuropathy in patients with type 2 diabetes. Diabetes Care 27: 179-183.

5. James JA, Poulton KV, Haworth SE, Payne D, McKay IJ, et al. (2007) Polymorphisms of TLR4 but not CD14 are associated with a decreased risk of aggressive periodontitis. J Clin Periodontol 34: 111-117.

6. Coughlin SR (2000) Thrombin signalling and protease-activated receptors Nature 407: 258-264

7. Coughlin SR, Camerer E (2003) PARticipation in inflammation. J Clin Invest 111: 25-27.

8. Holzhausen M, Spolidorio LC, Vergnolle N (2005) Role of protease-activated receptor- 2 in inflammation, and its possible implications as a putative mediator of periodontitis. Mem Inst Oswaldo Cruz 100 Suppl 1: 177-180.

9. Holzhausen M, Spolidorio LC, Ellen RP, Jobin MC, Steinhoff M, et al. (2006) Protease-activated receptor-2 activation: a major role in the pathogenesis of Porphyromonas gingivalis infection. Am J Pathol 168: 1189-1199.

10. Vergnolle $N$ (2009) Protease-activated receptors as drug targets in inflammation and pain. Pharmacol Ther 123: 292-309.

11. Holzhausen M, Cortelli JR, da Silva VA, Franco GC, Cortelli SC, et al. (2010) Protease-activated receptor-2 (PAR(2)) in human periodontitis. J Dent Res 89 948-953.

12. Chamaillard M, Girardin SE, Viala J, Philpott DJ (2003) Nods, Nalps and Naip: intracellular regulators of bacterial-induced inflammation. Cell Microbiol 5: 581 592.

13. Inohara N, Nuñez G (2003) NODs: intracellular proteins involved in inflammation and apoptosis. Nat Rev Immunol 3: 371-382.

14. Barnich N, Aguirre JE, Reinecker HC, Xavier R, Podolsky DK (2005) Membrane

*Corresponding author: Whasun O Chung, Department of Oral Health Sciences, University of Washington, Seattle, WA 98195-7475, Tel: 206-543-4339; E-mail sochung@u.washington.edu

Received December 18, 2015; Accepted December 21, 2015; Published December 23, 2015

Citation: Chung WO (2015) Receptors in Oral Epithelial Innate Immunity. J Bioanal Biomed 7: e134. doi:10.4172/1948-593X.1000e134

Copyright: (c) 2015 Chung WO. This is an open-access article distributed unde the terms of the Creative Commons Attribution License, which permits unrestricted use, distribution, and reproduction in any medium, provided the original author and source are credited. 
recruitment of NOD2 in intestinal epithelial cells is essential for nuclear factor\{kappa\}B activation in muramyl dipeptide recognition. The Journal of cell biology 170: 21-26

15. Viala J, Chaput C, Boneca IG, Cardona A, Girardin SE, et al. (2004) Nod1 responds to peptidoglycan delivered by the Helicobacter pylori cag pathogenicity island. Nat Immunol 5: 1166-1174

16. McGovern DP, Hysi P, Ahmad T, van Heel DA, Moffatt MF, et al. (2005) Association between a complex insertion/deletion polymorphism in NOD (CARD4) and susceptibility to inflammatory bowel disease. Hum Mol Genet 14: $1245-1250$

17. Hugot JP, Chamaillard M, Zouali H, Lesage S, Cézard JP, et al. (2001) Association of NOD2 leucine-rich repeat variants with susceptibility to Crohn's disease. Nature 411: 599-603.

18. Miceli-Richard C, Lesage S, Rybojad M, Prieur AM, Manouvrier-Hanu S, et al. (2001) CARD15 mutations in Blau syndrome. Nat Genet 29: 19-20.

19. Moore CB, Bergstralh DT, Duncan JA, Lei Y, Morrison TE, et al. (2008) NLRX1 is a regulator of mitochondrial antiviral immunity. Nature $451: 573-577$.
20. Pietras EM, Cheng G (2008) New tricks for old NODs. Genome Biol 9: 217.

21. Gil S, Coldwell S, Drury JL, Arroyo F, Phi T, et al. (2015) Genotype-specific regulation of oral innate immunity by T2R38 taste receptor. Mol Immunol 68 : $663-670$.

22. Kinnamon SC (2012) Taste receptor signalling - from tongues to lungs. Acta Physiol (Oxf) 204: 158-168.

23. Lee RJ, Xiong G, Kofonow JM, Chen B, Lysenko A, et al. (2012). T2R38 taste receptor polymorphisms underlie susceptibility to upper respiratory infection. $J$ Clin Invest 122: 4145-4159.

24. Eskan MA, Rose BG, Benakanakere MR, Zeng Q, Fujioka D, et al. (2008) TLR4 and $\mathrm{S} 1 \mathrm{P}$ receptors cooperate to enhance inflammatory cytokine production in human gingival epithelial cells. Eur J Immunol 38: 1138-1147.

25. Benakanakere MR, Zhao J, Galicia JC, Martin M, Kinane DF (2010) Sphingosine kinase-1 is required for toll mediated beta-defensin 2 induction in human oral keratinocytes. PLoS One 5: e11512.

26. Chung WO, An JY, Yin L, Hacker BM, Rohani MG, et al. (2010) Interplay of protease-activated receptors and NOD pattern recognition receptors in epithelial innate immune responses to bacteria. Immunology letters 131: 113119. 